\title{
L-Arginine and COVID-19: An Update
}

\author{
Ayobami Adebayo ${ }^{1}$, Fahimeh Varzideh ${ }^{1,2}$, Scott Wilson ${ }^{1}$, Jessica Gambardella ${ }^{1,2}$, Michael Eacobacci ${ }^{1}$, \\ Stanislovas S. Jankauskas ${ }^{1,2}{ }^{\mathbb{D}}$, Kwame Donkor ${ }^{1}$, Urna Kansakar ${ }^{1,2}$, Valentina Trimarco ${ }^{3}$, Pasquale Mone ${ }^{1}$, \\ Angela Lombardi ${ }^{1}$ and Gaetano Santulli ${ }^{1,2,4, *(1)}$
}

1 Department of Medicine, Einstein-Mount Sinai Diabetes Research Center (ES-DRC), Fleischer Institute for Diabetes and Metabolism (FIDAM), Einstein Institute for Aging Research, Albert Einstein College of Medicine, New York, NY 10461, USA; ayobami.adebayo@einsteinmed.org (A.A.); fahimeh.varzideh@einsteinmed.org (F.V.); scott.wilson@einsteinmed.org (S.W.); jessica.gambardella@einsteinmed.org (J.G.); michael.eacobacci@einsteinmed.org (M.E.); stanislovas.jankauskas@einsteinmed.org (S.S.J.); kwame.donkor@einsteinmed.org (K.D.); urna.kansakar@einsteinmed.org (U.K.); pasquale.mone@einsteinmed.org (P.M.); angela.lombardi@einsteinmed.org (A.L.)

2 Department of Molecular Pharmacology, Wilf Family Cardiovascular Research Institute, Einstein Institute for Neuroimmunology and Inflammation, Albert Einstein College of Medicine, New York, NY 10461, USA

3 Department of Neuroscience, "Federico II" University, 80131 Naples, Italy; valentina.trimarco@unina.it

4 Department of Advanced Biomedical Sciences, "Federico II" University and International Translational Research and Medical Education (ITME) Consortium, 80100 Naples, Italy

* Correspondence: gsantulli001@gmail.com

Citation: Adebayo, A.; Varzideh, F.; Wilson, S.; Gambardella, J.; Eacobacci, M.; Jankauskas, S.S.; Donkor, K.; Kansakar, U.; Trimarco, V.; Mone, P.; et al. L-Arginine and COVID-19: An Update. Nutrients 2021, 13, 3951. https://doi.org/10.3390/nu13113951

Academic Editors: Gregorio Paolo Milani and Carlo Agostoni

Received: 18 October 2021

Accepted: 3 November 2021

Published: 5 November 2021

Publisher's Note: MDPI stays neutral with regard to jurisdictional claims in published maps and institutional affiliations.

Copyright: (c) 2021 by the authors. Licensee MDPI, Basel, Switzerland. This article is an open access article distributed under the terms and conditions of the Creative Commons Attribution (CC BY) license (https:// creativecommons.org/licenses/by/ $4.0 /)$.

\begin{abstract}
L-Arginine is involved in many different biological processes and recent reports indicate that it could also play a crucial role in the coronavirus disease 2019 (COVID-19), caused by the severe acute respiratory syndrome coronavirus 2 (SARS-CoV-2). Herein, we present an updated systematic overview of the current evidence on the functional contribution of L-Arginine in COVID-19, describing its actions on endothelial cells and the immune system and discussing its potential as a therapeutic tool, emerged from recent clinical experimentations.
\end{abstract}

Keywords: antiviral therapies; arginine; cytokine storm; coronavirus; COVID-19; endothelium; immune response; immunity; inflammation; nitric oxide; nitrosylation; oxidative stress; ROS; SARS-CoV-2; T cells; viral infections

\section{Introduction}

L-Arginine is a semi-essential amino acid involved in numerous biological processes. It is a substrate for different enzymatic reactions and is metabolized using three major known pathways in the body: (1) Arginase metabolizes L-Arginine to L-ornithine, (2) L-Arginine decarboxylase metabolizes L-Arginine to agmatine, and (3) nitric oxide (NO) synthase (NOS) uses L-Arginine to form NO and citrulline [1-4].

\section{Functional Role of L-Arginine in NO Formation}

L-Arginine is the substrate used for NO production by NOS [5]; due to its ability to cause NO generation, which has been shown to be a major endothelial relaxation factor (able to increase vasodilation and reduce arterial blood pressure [4,6-8]), L-Arginine has considerable potential in becoming a tool to tackle cardiovascular issues [9]. For instance, in patients with known endothelial dysfunction, L-Arginine supplementation (6-8 g per day) has been shown to improve endothelial function and ultimately lower blood pressure [9].

Three isoforms of NOS have been identified; two of them (endothelial NOS [10,11] and neuronal NOS [12,13]) are expressed constitutively, while the last one is inducible and is mainly involved in the inflammatory/immune response [14-17].

In the reaction carried out by NOS, electrons are transferred to heme in the $N$-terminal domain $[18,19]$. Electrons are taken from nicotinamide adenine dinucleotide phosphate 
(NADP) using flavin adenine dinucleotide in the C-terminal reductase domain [20]. Once electrons are transferred to the $\mathrm{N}$ terminal oxygenase domain, $\mathrm{NO}$ and citrulline are formed via L-Arginine oxidation $[5,21,22]$. For NOS to function properly, there needs to be an ample amount of L-Arginine available for this reaction [23]. In addition, NADP, glutathione, tetrahydrobiopterin, and oxygen are needed for proper functioning [4,24].

A substrate competition occurs between NOS and arginase [25,26]. Although the affinity for L-Arginine in NOS is much higher than arginase, the speed of the reaction allows for substrate concentration. The speed of arginase rection is a thousand times faster than NOS [27]. Since these two enzymes compete for a common substrate, arginase will reduce the amount of L-Arginine available for NOS to use [28,29], ultimately decreasing the amount of NO produced.

\section{NO: Friend or Foe?}

$\mathrm{NO}$ is considered a signaling molecule involved in a number of processes, including inflammatory responses [30]. It is also essential in mediating vasodilation and bronchodilation, in addition to regulating neuronal function, signal transmission, and intraocular pressure [31].

$\mathrm{NO}$ acts as an antithrombotic and cytoprotective agent that impedes platelet adhesion, smooth muscle cell growth, and expression of adhesion molecules [32]. A reduction in NO levels triggers a dysregulated control of vascular tone as well as increased thickness and adhesiveness of the vascular wall [33]. NO can also prevent endothelial cells from undergoing programmed death [34].

On the other hand, NO has also been shown to have detrimental effects in many diseases. In some of these cases, there is a shift from the endothelial form (eNOS) of NO synthase to the inducible form (iNOS) $[35,36]$. Cells that are being damaged due to NO production will express nitrotyrosine, confirming damage from active free radicals [35]. Inflammatory cells are also known to produce free radicals that can cause a reaction with NO made from iNOS, forming peroxynitrate [37]. Peroxynitrate can have a pathogenic effect due to its ability to react with many different molecules, including lipids, amino acids, and nucleic bases. Therefore, peroxynitrate can lead to the dysfunction of tissues by causing a modification of the function of target molecules and their structures, including carbohydrates and lipids [33]. In addition, when peryoxynitrate reacts with nucleic bases, there is a break in single-stranded DNA, contributing to cell damage and apoptosis [38]. The production of free radicals is increased as the underlying diseases progress [39]. These findings suggest that $\mathrm{NO}$ and oxygen radicals can overpower the cellular defense mechanisms causing oxidative damage and cell death. Whether or not NO has a toxic or protective effect could depend on many factors [40].

Focusing on its action on viral infections, $\mathrm{NO}$ is known to have either indirect or direct antiviral activity. A direct effect of $\mathrm{NO}$ can lead to inhibition of viruses, and in fact, NO is considered one of the earliest antiviral responses of the host [41], whereas indirect effects include the regulation of inflammation and immune response [42]. NO also plays a key role in the generation of oxidized phospholipids [43], which can operate as potent immunomodulatory signals [44]. NO is necessary for the formation of several reactive oxygen and nitrogen species, including peryoxynitrite, dinitrogen trioxide, and nitrogen dioxide, which all can have an antiviral effect. However, these free radicals can also cause oxidative stress that can lead to severe cytotoxic effects. NO is known to act as a pro-apoptotic inducer in some cells or as an anti-apoptotic modulator in other cell types [45]. For instance, NO has been proposed to contribute to the persistence of hepatitis $\mathrm{C}$ virus due to its anti-apoptotic effect in hepatocytes [46-48]. Because of these aspects, NO can have both positive and negative roles in viral infections $[36,49,50]$. In summary, NO has antiviral effects that can be very useful from an immunologic standpoint; however, an excess of NO can also lead to cytotoxic effects [49] (Figure 1). 


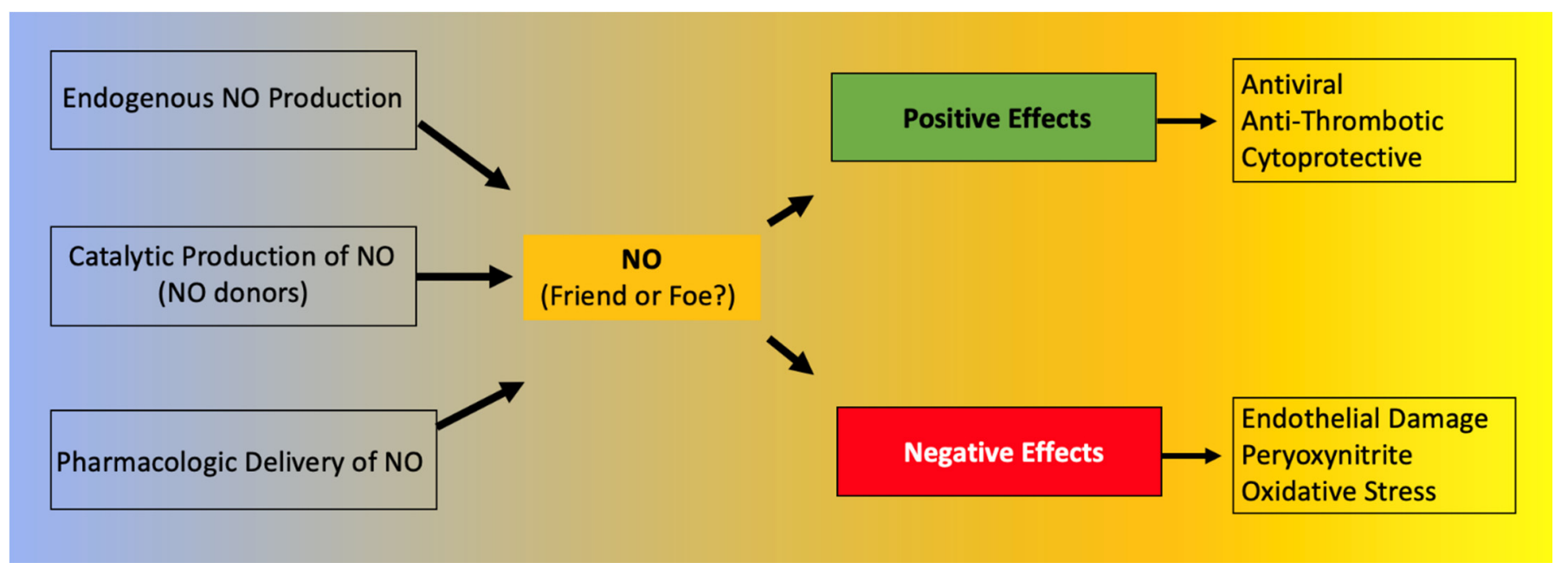

Figure 1. Positive and negative effects of nitric oxide (NO).

A clinical study conducted on 14 patients during the first outbreak of the severe acute respiratory syndrome coronavirus (SARS-CoV) in 2003 concluded that inhaled NO treatment for severely sick patients with SARS resulted in improvement of arterial oxygenation and allowed noninvasive pressure support to be discontinued [51]. SARS-CoV is a positive-sense RNA virus that has a genome of approximately thirty kilobases.

There are some structural proteins that are common among all forms of coronaviruses; these proteins include a nucleocapsid, membrane, envelope protein, and spike (S protein) [52-54]. The $\mathrm{S}$ protein of SARS-CoV interacts with angiotensin-converting enzyme 2 (ACE2) on the host cells; it has two domains: S1, which is used in receptor binding, and S2, involved in membrane fusion [55].

Akerstrom and colleagues demonstrated that NO inhibits certain steps of the SARS-CoV replication cycle in a concentration-dependent manner, although the exact underlying mechanism was not clarified [56]. In a follow-up study, the same authors proposed two specific mechanisms that NO uses to inhibit the replication of SARS-CoV [57]. The first mechanism involved the disruption of palmitoylating the $S$ protein (depalmytoilation). Such disruption affects the ability of the $\mathrm{S}$ protein to interact with ACE2. The second mechanism involved NO reducing the amount of viral RNA replication early on in the replication cycle due to an effect of the cysteine proteases encoded by SARS-CoV [57]; indeed, when Vero E6 cells were treated with S-nitroso- $\mathrm{N}$-acetylpenicillamine, a significant decrease in viral RNA production was detected three hours post-infection [57].

\section{Effects of L-Arginine on the Immune System}

A large part of a normal immune system depends on the amount of L-Arginine available in the body. Arginase is known to represent an integral part of certain granulocyte subsets, which can be released locally or systematically once there is an immune response. In addition, there is an accumulation of immature myeloid cells that express arginase, which is released when fighting off specific illnesses. These myeloid cells that express arginase can decrease the amount of L-Arginine [58-60].

$\mathrm{T}$ cell function has been shown to depend on L-Arginine levels [61,62]. A decreased ability of lymphocytes to proliferate has been reported in critically ill septic patients and correlated to reduced availability of L-Arginine [63]. Moreover, L-Arginine administration has been found to be beneficial to maintain immune homeostasis (Figure 2), especially in terms of $\mathrm{T}$ cell and macrophage function [64]. In fact, L-Arginine is essential in the macrophage M1-to-M2 switch [3]. 


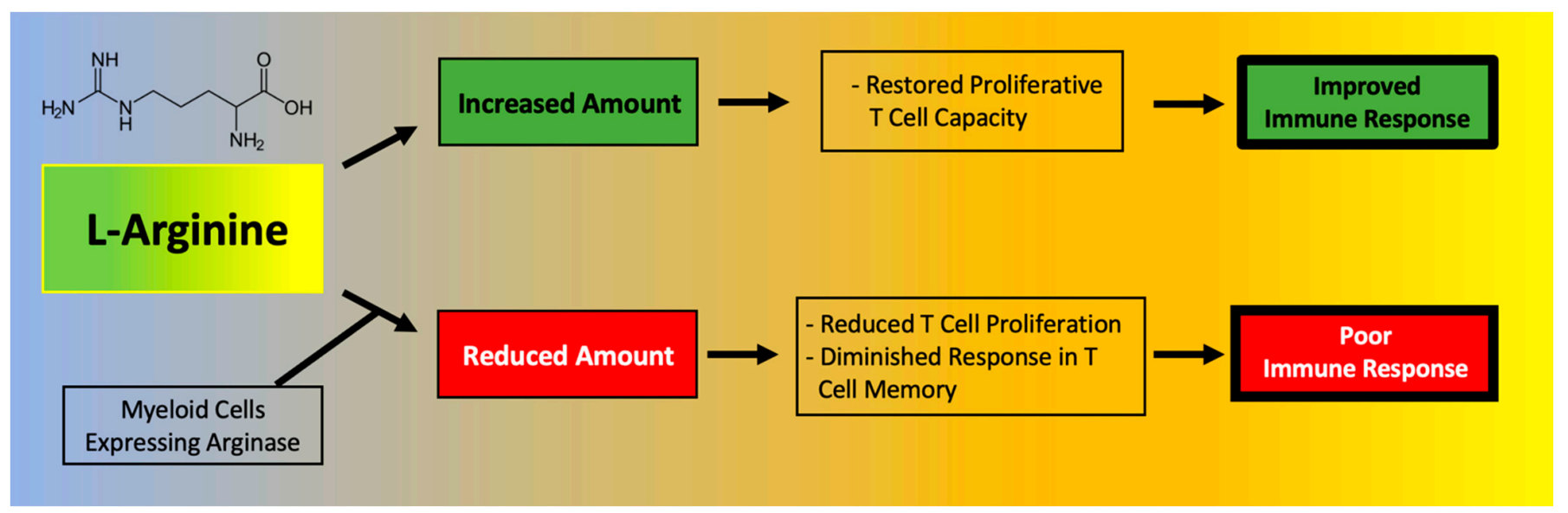

Figure 2. Main effects of L-Arginine on the immune system.

A deficiency in L-Arginine has been shown to lead to a reduction in $\mathrm{T}$ cell proliferation and to cause a diminished response in T cell-mediated memory [65]. In vitro assays have validated that L-Arginine can restore the function of T cells [66]. Mechanistically, the immunosuppressive effects of myeloid-derived suppressor cells (MDSCs) due to LArginine depletion and lymphocyte mitochondrial dysfunction have been demonstrated in models of cancer [61].

The expansion of MDSCs observed in COVID-19 has been directly correlated to enhanced arginase activity and lymphopenia [67]. Monocytic MDSCs were significantly expanded in the blood of COVID-19 patients and were strongly associated with disease severity; MDSCs were shown to suppress T cell proliferation and IFN $\gamma$ production, at least in part through an arginase-dependent mechanism, strongly indicating a role for these cells in the dysregulated COVID-19 immune response [68]. Indeed, MDSCs express high levels of arginase, which metabolizes L-Arginine to ornithine and urea, effectively depleting this amino acid from the microenvironment [69]. L-Arginine depletion is known to inhibit T cell receptor signaling, eventually resulting in T cell dysfunction [70] and to increase the generation of reactive oxygen species (ROS), thereby exacerbating inflammation $[69,71]$.

In a recent study focused on COVID-19, Dr. Claudia Morris and colleagues were able to determine the bioavailability of L-Arginine in three cohorts: asymptomatic healthy adults, adults hospitalized with COVID-19, and children hospitalized with COVID-19; they found that both adults and children affected by COVID-19 display significantly lower levels of plasma L-Arginine (as well as L-Arginine bioavailability) compared to controls [72]. Additionally, a low L-Arginine-to-ornithine ratio observed in COVID-19 patients [72] indicates an elevation of arginase activity in these patients. In another study, plasmatic L-Arginine levels were shown to inversely correlate with the severity of COVID-19 [73]. This study also revealed that the expression of the activated GPIIb/IIIa complex (PAC-1), known to be involved in platelet activation and thromboembolic events [74], is higher on platelets of patients with severe COVID-19 compared to healthy controls and inversely correlated with the plasmatic concentration of L-Arginine [73].

These pieces of evidence seem to go against the recently proposed strategy of L-Arginine depletion in COVID-19, based on the assumption that some steps in the viral lifecycle of SARS-CoV-2 could depend on L-Arginine residues (for instance, the nucleocapsid protein has a $6.9 \%$ L-Arginine content) [75].

In fact, a decrease in the bioavailability of L-Arginine has been shown to cause a diminished $\mathrm{T}$ cell response and function, eventually leading to an increased susceptibility to infections [76,77]. Twelve weeks of continuous L-Arginine supplementation significantly decreased the level of IL-21 [78], while NO has been shown to suppress the proliferation and function of human Th17 cells [79], which have been implied in the pathogenesis of the cytokine storm and of hyperinflammatory phenomena observed in COVID-19 patients [80-83]. Higher L-Arginine levels are associated with lower levels of CCL-20, a 
ligand for CCR6, a part of the chemotaxis system that is induced in response to coronavirus infections [81].

In vitro assays have demonstrated that the proliferative capacity of $\mathrm{T}$ cells is significantly reduced in COVID-19 patients and can be restored through L-Arginine supplementation [67]. Corroborating these findings, recent metabolomics data indicates that L-Arginine pathways are altered in COVID-19 patients [84] and an increased mRNA expression of arginase has also been found in the peripheral blood mononuclear cells (PBMCs) of COVID-19 patients [85].

Of note, circulating levels of metabolites of the L-Arginine pathway can be affected by arginase activity in red blood cells [86], which is known to be affected by oxidative stress and can contribute to endothelial dysfunction observed in COVID-19 [87]; furthermore, L-Arginine metabolism is known to be altered in hemolysis [88]. The exquisite balance between arginase and NOS activity has also been shown to influence the inflammatory responses of gut resident macrophages [3].

To actually test L-Arginine in COVID-19 patients, based on the rationale described above, we designed a randomized clinical trial to study the effects of adding L-Arginine orally (Bioarginina ${ }^{\circledR}, 1.66 \mathrm{~g}$ twice per day) to standard therapy in patients hospitalized for COVID-19. The interim results, recently published [89], revealed that patients who received L-Arginine had a significantly reduced duration of the in-hospital stay, and a diminished respiratory support, compared to patients in the placebo arm.

We speculate that L-Arginine supplementation could be also beneficial in controlling long-COVID-19, since the persistence of chronic inflammation and endothelial dysfunction has been shown to be fundamental in COVID-19 sequelae [90-93].

\section{L-Arginine Deficiency in African Americans: Implications in COVID-19}

The deficiency in L-Arginine could be one of the reasons why African Americans suffer more from cardiovascular disease than other races [94-97]. For instance, a study completed by Glyn and collaborators compared the L-Arginine profile of African and Caucasian men of similar ages and cardiovascular risk factors. What they found was that levels of L-Arginine were significantly lower in African men while blood pressure and pulse wave velocity were higher [98]. In this study, African American men typically presented with extremely detrimental cardiovascular factors. A total of 292 men (130 of them being African and 162 of them being Caucasian) were studied; in African men, the average level of L-Arginine measured was $107 \pm 25.6 \mu \mathrm{mol} / \mathrm{L}$, whereas Caucasian men were found to have an average L-Arginine level of $126 \pm 32.8 \mu \mathrm{mol} / \mathrm{L}(p<0.001)$. However, the authors were not able to determine whether or not the differences in L-Arginine levels were environmentally induced or imposed genetically [98].

The deficiency in L-Arginine and L-Arginine derived NO [99,100] could also explain the differences reported in terms of COVID-19 and race [101,102]. In support of this view, the intracoronary infusion of L-Arginine was recently found to have a greater effect on endothelium-dependent vascular relaxation in African Americans than in Caucasian subjects [103].

\section{Conclusions and Perspectives}

The functional contribution of L-Arginine in many biological processes is extremely significant, especially in the control of endothelial and immune activities. There is a strong rationale indicating a beneficial effect of L-Arginine in COVID-19, and preliminary results from a randomized clinical trial seem to support this view.

Author Contributions: Conceptualization, G.S.; writing-original draft preparation, A.A., F.V., J.G., S.S.J., U.K. and A.L.; writing-review and editing, S.W., M.E., K.D., V.T., P.M. and G.S.; supervision, G.S. All authors have read and agreed to the published version of the manuscript. 
Funding: The Santulli's Lab is supported in part by the National Institutes of Health (NIH: R01HL146691, R01-DK123259, R01-HL159062, R01-DK033823, R56-AG066431, T32-HL144456, and R00DK107895, to G.S.), by the Irma T. Hirschl and Monique Weill-Caulier Trusts (to G.S.), by the Diabetes Action Research and Education Foundation (to G.S.), and by the American Heart Association (AHA21POST836407 to S.S.J. and AHA-20POST35211151 to J.G.).

Institutional Review Board Statement: Not applicable.

Informed Consent Statement: Not applicable.

Conflicts of Interest: The authors declare no conflict of interest.

\section{References}

1. Brosnan, M.E.; Brosnan, J.T. Renal arginine metabolism. J. Nutr. 2004, 134, 2791S-2795S. [CrossRef]

2. Wu, G.; Meininger, C.J.; McNeal, C.J.; Bazer, F.W.; Rhoads, J.M. Role of L-Arginine in Nitric Oxide Synthesis and Health in Humans. Adv. Exp. Med. Biol. 2021, 1332, 167-187. [CrossRef]

3. Rath, M.; Muller, I.; Kropf, P.; Closs, E.I.; Munder, M. Metabolism via Arginase or Nitric Oxide Synthase: Two Competing Arginine Pathways in Macrophages. Front. Immunol. 2014, 5, 532. [CrossRef]

4. Gambardella, J.; Khondkar, W.; Morelli, M.B.; Wang, X.; Santulli, G.; Trimarco, V. Arginine and Endothelial Function. Biomedicines 2020, 8, 277. [CrossRef]

5. Andrew, P.J.; Mayer, B. Enzymatic function of nitric oxide synthases. Cardiovasc. Res. 1999, 43, 521-531. [CrossRef]

6. Jorens, P.G.; Vermeire, P.A.; Herman, A.G. L-Arginine-dependent nitric oxide synthase: A new metabolic pathway in the lung and airways. Eur. Respir. J. 1993, 6, 258-266.

7. Tousoulis, D.; Kampoli, A.M.; Tentolouris, C.; Papageorgiou, N.; Stefanadis, C. The role of nitric oxide on endothelial function. Curr. Vasc. Pharmacol. 2012, 10, 4-18. [CrossRef]

8. Dormanns, K.; Brown, R.G.; David, T. The role of nitric oxide in neurovascular coupling. J. Theor. Biol. 2016, 394, 1-17. [CrossRef]

9. Ströhle, A.; von Bibra, H.; Hahn, A. L-Arginine and vascular health. Med. Monatsschr. Pharm. 2016, 39, 515-520.

10. Albrecht, E.W.; Stegeman, C.A.; Heeringa, P.; Henning, R.H.; van Goor, H. Protective role of endothelial nitric oxide synthase. J. Pathol. 2003, 199, 8-17. [CrossRef]

11. Chatterjee, A.; Black, S.M.; Catravas, J.D. Endothelial nitric oxide (NO) and its pathophysiologic regulation. Vascul. Pharmacol. 2008, 49, 134-140. [CrossRef]

12. Sezen, S.F.; Lagoda, G.; Burnett, A.L. Neuronal nitric oxide signaling regulates erection recovery after cavernous nerve injury. J. Urol. 2012, 187, 757-763. [CrossRef]

13. Bredt, D.S.; Snyder, S.H. Nitric oxide, a novel neuronal messenger. Neuron 1992, 8, 3-11. [CrossRef]

14. Chakravortty, D.; Hensel, M. Inducible nitric oxide synthase and control of intracellular bacterial pathogens. Microbes Infect. 2003, 5, 621-627. [CrossRef]

15. Lee, M.; Rey, K.; Besler, K.; Wang, C.; Choy, J. Immunobiology of Nitric Oxide and Regulation of Inducible Nitric Oxide Synthase. Results Probl. Cell Differ. 2017, 62, 181-207. [CrossRef]

16. Sharma, J.N.; Al-Omran, A.; Parvathy, S.S. Role of nitric oxide in inflammatory diseases. Inflammopharmacology 2007, 15, 252-259. [CrossRef]

17. Schini, V.B.; Busse, R.; Vanhoutte, P.M. Inducible nitric oxide synthase in vascular smooth muscle. Arzneimittelforschung 1994, 44, 432-435.

18. Stuehr, D.J. Enzymes of the L-Arginine to nitric oxide pathway. J. Nutr. 2004, 134, 2748S-2751S. [CrossRef]

19. Forstermann, U.; Sessa, W.C. Nitric oxide synthases: Regulation and function. Eur. Heart J. 2012, 33, 829-837. [CrossRef]

20. Mori, M. Regulation of nitric oxide synthesis and apoptosis by arginase and arginine recycling. J. Nutr. 2007, 137, 1616S-1620S. [CrossRef]

21. Agapie, T.; Suseno, S.; Woodward, J.J.; Stoll, S.; Britt, R.D.; Marletta, M.A. NO formation by a catalytically self-sufficient bacterial nitric oxide synthase from Sorangium cellulosum. Proc. Natl. Acad. Sci. USA 2009, 106, 16221-16226. [CrossRef] [PubMed]

22. Jáchymová, M.; Martásek, P.; Panda, S.; Roman, L.J.; Panda, M.; Shea, T.M.; Ishimura, Y.; Kim, J.J.; Masters, B.S. Recruitment of governing elements for electron transfer in the nitric oxide synthase family. Proc. Natl. Acad. Sci. USA 2005, 102, 15833-15838. [CrossRef] [PubMed]

23. Rajapakse, N.W.; Mattson, D.L. Role of L-Arginine in nitric oxide production in health and hypertension. Clin. Exp. Pharmacol. Physiol. 2009, 36, 249-255. [CrossRef]

24. Stuehr, D.J.; Kwon, N.S.; Nathan, C.F. FAD and GSH participate in macrophage synthesis of nitric oxide. Biochem. Biophys. Res. Commun. 1990, 168, 558-565. [CrossRef]

25. Durante, W.; Johnson, F.K.; Johnson, R.A. Arginase: A critical regulator of nitric oxide synthesis and vascular function. Clin. Exp. Pharmacol. Physiol. 2007, 34, 906-911. [CrossRef]

26. Morris, C.R. Mechanisms of vasculopathy in sickle cell disease and thalassemia. Hematology Am. Soc. Hematol. Educ. Program. 2008, 2008, 177-185. [CrossRef] [PubMed]

27. Wu, G.; Morris, S.M., Jr. Arginine metabolism: Nitric oxide and beyond. Biochem. J. 1998, 336, 1-17. [CrossRef] 
28. S Clemente, G.; van Waarde, A.; F Antunes, I.; Dömling, A.; H Elsinga, P. Arginase as a Potential Biomarker of Disease Progression: A Molecular Imaging Perspective. Int. J. Mol. Sci. 2020, 21, 5291. [CrossRef]

29. Benson, R.C.; Hardy, K.A.; Morris, C.R. Arginase and arginine dysregulation in asthma. J. Allergy 2011, 2011, 736319. [CrossRef]

30. Fang, F.C. Antimicrobial reactive oxygen and nitrogen species: Concepts and controversies. Nat. Rev. Microbiol. 2004, 2, 820-832. [CrossRef]

31. Lisi, F.; Zelikin, A.N.; Chandrawati, R. Nitric Oxide to Fight Viral Infections. Adv. Sci. 2021, 8, 2003895. [CrossRef]

32. Ignarro, L.J. Endothelium-derived nitric oxide: Actions and properties. Faseb J. 1989, 3, 31-36. [CrossRef]

33. Matucci Cerinic, M.; Kahaleh, M.B. Beauty and the Beast. The nitric oxide paradox in systemic sclerosis. Rheumatology 2002, 41, 843-847. [CrossRef] [PubMed]

34. Rössig, L.; Haendeler, J.; Hermann, C.; Malchow, P.; Urbich, C.; Zeiher, A.M.; Dimmeler, S. Nitric oxide down-regulates MKP-3 mRNA levels: Involvement in endothelial cell protection from apoptosis. J. Biol. Chem. 2000, 275, 25502-25507. [CrossRef]

35. Cotton, S.A.; Herrick, A.L.; Jayson, M.I.; Freemont, A.J. Endothelial expression of nitric oxide synthases and nitrotyrosine in systemic sclerosis skin. J. Pathol. 1999, 189, 273-278. [CrossRef]

36. Perrone, L.A.; Belser, J.A.; Wadford, D.A.; Katz, J.M.; Tumpey, T.M. Inducible nitric oxide contributes to viral pathogenesis following highly pathogenic influenza virus infection in mice. J. Infect. Dis. 2013, 207, 1576-1584. [CrossRef]

37. Herrick, A.L.; Matucci Cerinic, M. The emerging problem of oxidative stress and the role of antioxidants in systemic sclerosis. Clin. Exp. Rheumatol. 2001, 19,4-8.

38. Cuzzocrea, S.; Zingarelli, B.; O'Connor, M.; Salzman, A.L.; Caputi, A.P.; Szabó, C. Role of peroxynitrite and activation of poly (ADPribose) synthase in the vascular failure induced by zymosan-activated plasma. Br. J. Pharmacol. 1997, 122, 493-503. [CrossRef]

39. Sharifi-Rad, M.; Anil Kumar, N.V.; Zucca, P.; Varoni, E.M.; Dini, L.; Panzarini, E.; Rajkovic, J.; Tsouh Fokou, P.V.; Azzini, E.; Peluso, I.; et al. Lifestyle, Oxidative Stress, and Antioxidants: Back and Forth in the Pathophysiology of Chronic Diseases. Front. Physiol. 2020, 11, 694. [CrossRef]

40. Zorov, D.B.; Juhaszova, M.; Sollott, S.J. Mitochondrial reactive oxygen species (ROS) and ROS-induced ROS release. Physiol. Rev. 2014, 94, 909-950. [CrossRef]

41. Bogdan, C. Nitric oxide and the immune response. Nat. Immunol. 2001, 2, 907-916. [CrossRef] [PubMed]

42. Torre, D.; Pugliese, A.; Speranza, F. Role of nitric oxide in HIV-1 infection: Friend or foe? Lancet Infect. Dis. 2002, 2, 273-280. [CrossRef]

43. Gharavi, N.M.; Baker, N.A.; Mouillesseaux, K.P.; Yeung, W.; Honda, H.M.; Hsieh, X.; Yeh, M.; Smart, E.J.; Berliner, J.A. Role of endothelial nitric oxide synthase in the regulation of SREBP activation by oxidized phospholipids. Circ. Res. 2006, 98, 768-776. [CrossRef] [PubMed]

44. Zhivaki, D.; Kagan, J.C. Innate immune detection of lipid oxidation as a threat assessment strategy. Nat. Rev. Immunol. 2021. [CrossRef]

45. Zamora, R.; Vodovotz, Y.; Billiar, T.R. Inducible nitric oxide synthase and inflammatory diseases. Mol. Med. 2000, 6, 347-373. [CrossRef]

46. Chung, H.T.; Pae, H.O.; Choi, B.M.; Billiar, T.R.; Kim, Y.M. Nitric oxide as a bioregulator of apoptosis. Biochem. Biophys. Res. Commun. 2001, 282, 1075-1079. [CrossRef]

47. Majano, P.L.; Garcia-Monzon, C. Does nitric oxide play a pathogenic role in hepatitis C virus infection? Cell Death Differ. 2003, 10 (Suppl. 1), S13-S15. [CrossRef]

48. Izzo, F.; Montella, M.; Orlando, A.P.; Nasti, G.; Beneduce, G.; Castello, G.; Cremona, F.; Ensor, C.M.; Holtzberg, F.W.; Bomalaski, J.S.; et al. Pegylated arginine deiminase lowers hepatitis $\mathrm{C}$ viral titers and inhibits nitric oxide synthesis. J. Gastroenterol. Hepatol. 2007, 22, 86-91. [CrossRef] [PubMed]

49. Burgner, D.; Rockett, K.; Kwiatkowski, D. Nitric oxide and infectious diseases. Arch. Dis. Child 1999, 81, 185-188. [CrossRef]

50. Kharitonov, S.A.; Yates, D.; Barnes, P.J. Increased nitric oxide in exhaled air of normal human subjects with upper respiratory tract infections. Eur. Respir. J. 1995, 8, 295-297. [CrossRef]

51. Chen, L.; Liu, P.; Gao, H.; Sun, B.; Chao, D.; Wang, F.; Zhu, Y.; Hedenstierna, G.; Wang, C.G. Inhalation of nitric oxide in the treatment of severe acute respiratory syndrome: A rescue trial in Beijing. Clin. Infect. Dis. 2004, 39, 1531-1535. [CrossRef]

52. Tan, Y.J.; Lim, S.G.; Hong, W. Understanding the accessory viral proteins unique to the severe acute respiratory syndrome (SARS) coronavirus. Antiviral. Res. 2006, 72, 78-88. [CrossRef] [PubMed]

53. Marra, M.A.; Jones, S.J.; Astell, C.R.; Holt, R.A.; Brooks-Wilson, A.; Butterfield, Y.S.; Khattra, J.; Asano, J.K.; Barber, S.A.; Chan, S.Y.; et al. The Genome sequence of the SARS-associated coronavirus. Science 2003, 300, 1399-1404. [CrossRef]

54. McBride, R.; van Zyl, M.; Fielding, B.C. The coronavirus nucleocapsid is a multifunctional protein. Viruses 2014, 6, 2991-3018. [CrossRef] [PubMed]

55. Li, F.; Li, W.; Farzan, M.; Harrison, S.C. Structure of SARS coronavirus spike receptor-binding domain complexed with receptor. Science 2005, 309, 1864-1868. [CrossRef] [PubMed]

56. Akerström, S.; Mousavi-Jazi, M.; Klingström, J.; Leijon, M.; Lundkvist, A.; Mirazimi, A. Nitric oxide inhibits the replication cycle of severe acute respiratory syndrome coronavirus. J. Virol. 2005, 79, 1966-1969. [CrossRef]

57. Akerström, S.; Gunalan, V.; Keng, C.T.; Tan, Y.J.; Mirazimi, A. Dual effect of nitric oxide on SARS-CoV replication: Viral RNA production and palmitoylation of the $S$ protein are affected. Virology 2009, 395, 1-9. [CrossRef]

58. Popovic, P.J.; Zeh, H.J., 3rd; Ochoa, J.B. Arginine and immunity. J. Nutr. 2007, 137, 1681s-1686s. [CrossRef] 
59. Szefel, J.; Danielak, A.; Kruszewski, W.J. Metabolic pathways of L-Arginine and therapeutic consequences in tumors. Adv. Med. Sci. 2019, 64, 104-110. [CrossRef] [PubMed]

60. Steggerda, S.M.; Bennett, M.K.; Chen, J.; Emberley, E.; Huang, T.; Janes, J.R.; Li, W.; MacKinnon, A.L.; Makkouk, A.; Marguier, G.; et al. Inhibition of arginase by CB-1158 blocks myeloid cell-mediated immune suppression in the tumor microenvironment. $J$. Immunother. Cancer 2017, 5, 101. [CrossRef] [PubMed]

61. Geiger, R.; Rieckmann, J.C.; Wolf, T.; Basso, C.; Feng, Y.; Fuhrer, T.; Kogadeeva, M.; Picotti, P.; Meissner, F.; Mann, M.; et al. L-Arginine Modulates T Cell Metabolism and Enhances Survival and Anti-tumor Activity. Cell 2016, 167, 829-842.e813. [CrossRef]

62. Li, P.; Yin, Y.L.; Li, D.; Kim, S.W.; Wu, G. Amino acids and immune function. Br. J. Nutr. 2007, 98, 237-252. [CrossRef]

63. Uhel, F.; Azzaoui, I.; Gregoire, M.; Pangault, C.; Dulong, J.; Tadie, J.M.; Gacouin, A.; Camus, C.; Cynober, L.; Fest, T.; et al. Early Expansion of Circulating Granulocytic Myeloid-derived Suppressor Cells Predicts Development of Nosocomial Infections in Patients with Sepsis. Am. J. Respir. Crit. Care Med. 2017, 196, 315-327. [CrossRef] [PubMed]

64. Tepaske, R.; Velthuis, H.; Oudemans-van Straaten, H.M.; Heisterkamp, S.H.; van Deventer, S.J.; Ince, C.; Eysman, L.; Kesecioglu, J. Effect of preoperative oral immune-enhancing nutritional supplement on patients at high risk of infection after cardiac surgery: A randomised placebo-controlled trial. Lancet 2001, 358, 696-701. [CrossRef]

65. Zhu, X.; Pribis, J.P.; Rodriguez, P.C.; Morris, S.M., Jr.; Vodovotz, Y.; Billiar, T.R.; Ochoa, J.B. The central role of arginine catabolism in T-cell dysfunction and increased susceptibility to infection after physical injury. Ann. Surg. 2014, 259, 171-178. [CrossRef]

66. Bronte, V.; Zanovello, P. Regulation of immune responses by L-Arginine metabolism. Nat. Rev. Immunol. 2005, 5, 641-654. [CrossRef]

67. Reizine, F.; Lesouhaitier, M.; Gregoire, M.; Pinceaux, K.; Gacouin, A.; Maamar, A.; Painvin, B.; Camus, C.; Le Tulzo, Y.; Tattevin, P.; et al. SARS-CoV-2-Induced ARDS Associates with MDSC Expansion, Lymphocyte Dysfunction, and Arginine Shortage. J. Clin. Immunol. 2021, 41, 515-525. [CrossRef] [PubMed]

68. Falck-Jones, S.; Vangeti, S.; Yu, M.; Falck-Jones, R.; Cagigi, A.; Badolati, I.; Osterberg, B.; Lautenbach, M.J.; Ahlberg, E.; Lin, A.; et al. Functional monocytic myeloid-derived suppressor cells increase in blood but not airways and predict COVID-19 severity. $J$. Clin. Investig. 2021, 131, e144734. [CrossRef] [PubMed]

69. Dean, M.J.; Ochoa, J.B.; Sanchez-Pino, M.D.; Zabaleta, J.; Garai, J.; Del Valle, L.; Wyczechowska, D.; Baiamonte, L.B.; Philbrook, P.; Majumder, R.; et al. Severe COVID-19 Is Characterized by an Impaired Type I Interferon Response and Elevated Levels of Arginase Producing Granulocytic Myeloid Derived Suppressor Cells. Front. Immunol. 2021, 12, 695972. [CrossRef]

70. Rodriguez, P.C.; Ochoa, A.C. Arginine regulation by myeloid derived suppressor cells and tolerance in cancer: Mechanisms and therapeutic perspectives. Immunol. Rev. 2008, 222, 180-191. [CrossRef]

71. Lucas, R.; Czikora, I.; Sridhar, S.; Zemskov, E.A.; Oseghale, A.; Circo, S.; Cederbaum, S.D.; Chakraborty, T.; Fulton, D.J.; Caldwell, R.W.; et al. Arginase 1: An unexpected mediator of pulmonary capillary barrier dysfunction in models of acute lung injury. Front. Immunol. 2013, 4, 228. [CrossRef] [PubMed]

72. Rees, C.A.; Rostad, C.A.; Mantus, G.; Anderson, E.J.; Chahroudi, A.; Jaggi, P.; Wrammert, J.; Ochoa, J.B.; Ochoa, A.; Basu, R.K.; et al. Altered amino acid profile in patients with SARS-CoV-2 infection. Proc. Natl. Acad. Sci. USA 2021, 118. [CrossRef]

73. Sacchi, A.; Grassi, G.; Notari, S.; Gili, S.; Bordoni, V.; Tartaglia, E.; Casetti, R.; Cimini, E.; Mariotti, D.; Garotto, G.; et al. Expansion of Myeloid Derived Suppressor Cells Contributes to Platelet Activation by L-Arginine Deprivation during SARS-CoV-2 Infection. Cells 2021, 10, 2111. [CrossRef]

74. Chen, Z.; Mondal, N.K.; Ding, J.; Koenig, S.C.; Slaughter, M.S.; Griffith, B.P.; Wu, Z.J. Activation and shedding of platelet glycoprotein IIb/IIIa under non-physiological shear stress. Mol. Cell Biochem. 2015, 409, 93-101. [CrossRef]

75. Grimes, J.M.; Khan, S.; Badeaux, M.; Rao, R.M.; Rowlinson, S.W.; Carvajal, R.D. Arginine depletion as a therapeutic approach for patients with COVID-19. Int. J. Infect. Dis. 2021, 102, 566-570. [CrossRef]

76. Ochoa, J.B.; Bernard, A.C.; O’Brien, W.E.; Griffen, M.M.; Maley, M.E.; Rockich, A.K.; Tsuei, B.J.; Boulanger, B.R.; Kearney, P.A.; Morris, S.M., Jr. Arginase I expression and activity in human mononuclear cells after injury. Ann. Surg. 2001, 233, 393-399. [CrossRef]

77. Ochoa, J.B.; Bernard, A.C.; Mistry, S.K.; Morris, S.M., Jr.; Figert, P.L.; Maley, M.E.; Tsuei, B.J.; Boulanger, B.R.; Kearney, P.A. Trauma increases extrahepatic arginase activity. Surgery 2000, 127, 419-426. [CrossRef] [PubMed]

78. Liao, S.Y.; Linderholm, A.; Showalter, M.R.; Chen, C.H.; Fiehn, O.; Kenyon, N.J. L-Arginine as a potential GLP-1-mediated immunomodulator of Th17-related cytokines in people with obesity and asthma. Obes. Sci. Pract. 2021, 7, 339-345. [CrossRef]

79. Niedbala, W.; Alves-Filho, J.C.; Fukada, S.Y.; Vieira, S.M.; Mitani, A.; Sonego, F.; Mirchandani, A.; Nascimento, D.C.; Cunha, F.Q.; Liew, F.Y. Regulation of type 17 helper T-cell function by nitric oxide during inflammation. Proc. Natl. Acad. Sci. USA 2011, 108, 9220-9225. [CrossRef] [PubMed]

80. Xu, Z.; Shi, L.; Wang, Y.; Zhang, J.; Huang, L.; Zhang, C.; Liu, S.; Zhao, P.; Liu, H.; Zhu, L.; et al. Pathological findings of COVID-19 associated with acute respiratory distress syndrome. Lancet Respir. Med. 2020, 8, 420-422. [CrossRef]

81. Thomassen, M.J.; Buhrow, L.T.; Connors, M.J.; Kaneko, F.T.; Erzurum, S.C.; Kavuru, M.S. Nitric oxide inhibits inflammatory cytokine production by human alveolar macrophages. Am. J. Respir. Cell Mol. Biol. 1997, 17, 279-283. [CrossRef]

82. Hotez, P.J.; Bottazzi, M.E.; Corry, D.B. The potential role of Th17 immune responses in coronavirus immunopathology and vaccine-induced immune enhancement. Microbes. Infect. 2020, 22, 165-167. [CrossRef]

83. Wu, D.; Yang, X.O. TH17 responses in cytokine storm of COVID-19: An emerging target of JAK2 inhibitor Fedratinib. J. Microbiol. Immunol. Infect. 2020, 53, 368-370. [CrossRef] 
84. D'Alessandro, A.; Akpan, I.; Thomas, T.; Reisz, J.; Cendali, F.; Gamboni, F.; Nemkov, T.; Thangaraju, K.; Katneni, U.; Tanaka, K.; et al. Biological and Clinical Factors contributing to the Metabolic Heterogeneity of Hospitalized Patients with and without COVID-19. Cells 2021, 10, 2293. [CrossRef]

85. Derakhshani, A.; Hemmat, N.; Asadzadeh, Z.; Ghaseminia, M.; Shadbad, M.A.; Jadideslam, G.; Silvestris, N.; Racanelli, V.; Baradaran, B. Arginase 1 (Arg1) as an Up-Regulated Gene in COVID-19 Patients: A Promising Marker in COVID-19 Immunopathy. J. Clin. Med. 2021, 10, 1051. [CrossRef]

86. Renoux, C.; Fort, R.; Nader, E.; Boisson, C.; Joly, P.; Stauffer, E.; Robert, M.; Girard, S.; Cibiel, A.; Gauthier, A.; et al. Impact of COVID-19 on red blood cell rheology. Br. J. Haematol. 2021, 192, e108-e111. [CrossRef] [PubMed]

87. Hoffmann, M.; Kleine-Weber, H.; Schroeder, S.; Kruger, N.; Herrler, T.; Erichsen, S.; Schiergens, T.S.; Herrler, G.; Wu, N.H.; Nitsche, A.; et al. SARS-CoV-2 Cell Entry Depends on ACE2 and TMPRSS2 and Is Blocked by a Clinically Proven Protease Inhibitor. Cell 2020, 181, 271-280.e278. [CrossRef] [PubMed]

88. Morris, C.R.; Kato, G.J.; Poljakovic, M.; Wang, X.; Blackwelder, W.C.; Sachdev, V.; Hazen, S.L.; Vichinsky, E.P.; Morris, S.M., Jr.; Gladwin, M.T. Dysregulated arginine metabolism, hemolysis-associated pulmonary hypertension, and mortality in sickle cell disease. JAMA 2005, 294, 81-90. [CrossRef] [PubMed]

89. Fiorentino, G.; Coppola, A.; Izzo, R.; Annunziata, A.; Bernardo, M.; Lombardi, A.; Trimarco, V.; Santulli, G.; Trimarco, B. Effects of adding L-Arginine orally to standard therapy in patients with COVID-19: A randomized, double-blind, placebo-controlled, parallel-group trial. Results of the first interim analysis. EClinicalMedicine 2021, 40, 101125. [CrossRef]

90. Yan, Z.; Yang, M.; Lai, C.L. Long COVID-19 Syndrome: A Comprehensive Review of Its Effect on Various Organ Systems and Recommendation on Rehabilitation Plans. Biomedicines 2021, 9, 966. [CrossRef]

91. Paul, B.D.; Lemle, M.D.; Komaroff, A.L.; Snyder, S.H. Redox imbalance links COVID-19 and myalgic encephalomyelitis/chronic fatigue syndrome. Proc. Natl. Acad. Sci. USA 2021, 118, e2024358118. [CrossRef]

92. Paneroni, M.; Pasini, E.; Vitacca, M.; Scalvini, S.; Comini, L.; Pedrinolla, A.; Venturelli, M. Altered Vascular EndotheliumDependent Responsiveness in Frail Elderly Patients Recovering from COVID-19 Pneumonia: Preliminary Evidence. J. Clin. Med. 2021, 10, 2558. [CrossRef]

93. Roe, K. A role for T-cell exhaustion in Long COVID-19 and severe outcomes for several categories of COVID-19 patients. $J$ Neurosci. Res. 2021, in press. [CrossRef]

94. Golestaneh, L.; Neugarten, J.; Fisher, M.; Billett, H.H.; Gil, M.R.; Johns, T.; Yunes, M.; Mokrzycki, M.H.; Coco, M.; Norris, K.C.; et al. The association of race and COVID-19 mortality. EClinicalMedicine 2020, 25, 100455. [CrossRef]

95. Kabarriti, R.; Brodin, N.P.; Maron, M.I.; Guha, C.; Kalnicki, S.; Garg, M.K.; Racine, A.D. Association of Race and Ethnicity With Comorbidities and Survival Among Patients With COVID-19 at an Urban Medical Center in New York. JAMA Netw. Open 2020, 3 , e2019795. [CrossRef]

96. Chin-Hong, P.; Alexander, K.M.; Haynes, N.; Albert, M.A.; Association of Black, C. Pulling at the heart: COVID-19, race/ethnicity and ongoing disparities. Nat. Rev. Cardiol. 2020, 17, 533-535. [CrossRef] [PubMed]

97. Chaudhary, R.; Bliden, K.P.; Kreutz, R.P.; Jeong, Y.H.; Tantry, U.S.; Levy, J.H.; Gurbel, P.A. Race-Related disparities in COVID-19 thrombotic outcomes: Beyond social and economic explanations. EClinicalMedicine 2020, 29, 100647. [CrossRef]

98. Glyn, M.C.; Anderssohn, M.; Lüneburg, N.; Van Rooyen, J.M.; Schutte, R.; Huisman, H.W.; Fourie, C.M.T.; Smith, W.; Malan, L.; Malan, N.T.; et al. Ethnicity-specific differences in L-Arginine status in South African men. J. Hum. Hypertens. 2012, 26, 737-743. [CrossRef] [PubMed]

99. Mata-Greenwood, E.; Chen, D.B. Racial differences in nitric oxide-dependent vasorelaxation. Reprod. Sci. 2008, 15, 9-25. [CrossRef]

100. Melikian, N.; Wheatcroft, S.B.; Ogah, O.S.; Murphy, C.; Chowienczyk, P.J.; Wierzbicki, A.S.; Sanders, T.A.; Jiang, B.; Duncan, E.R.; Shah, A.M.; et al. Asymmetric dimethylarginine and reduced nitric oxide bioavailability in young Black African men. Hypertension 2007, 49, 873-877. [CrossRef] [PubMed]

101. Kullar, R.; Marcelin, J.R.; Swartz, T.H.; Piggott, D.A.; Macias Gil, R.; Mathew, T.A.; Tan, T. Racial Disparity of Coronavirus Disease 2019 in African American Communities. J. Infect. Dis. 2020, 222, 890-893. [CrossRef] [PubMed]

102. Vasquez Reyes, M. The Disproportional Impact of COVID-19 on African Americans. Health Hum. Rights 2020, 22, 299-307. [PubMed]

103. Houghton, J.L.; Philbin, E.F.; Strogatz, D.S.; Torosoff, M.T.; Fein, S.A.; Kuhner, P.A.; Smith, V.E.; Carr, A.A. The presence of African American race predicts improvement in coronary endothelial function after supplementary L-Arginine. J. Am. Coll. Cardiol. 2002, 39, 1314-1322. [CrossRef] 